\title{
Suboptimal Utilisation of Resources in Sub-Saharan African Higher Education Institutions: the Case of Teaching Space at Makerere University
}

\author{
Jude Ssempebwa $^{1, *}$, S. O. Owolabi ${ }^{2}$, F. E. K. Bakkabulindi ${ }^{3}$
}

(C) Uganda Martyrs University

\begin{abstract}
Many higher education institutions in Sub-Saharan Africa are underfunded. Consequently, they are operating with encumbering resources constraints that threaten quality assurance. Accordingly, they are working to expand the availability of these resources. Notwithstanding, it is taken for granted that once available, these resources are optimally utilized and that, in instances expanding their availability is not possible, compromising on some elements of the quality of higher education is inevitable. The problem is that this presumption could disguise inadequacies in the utilization of the resources, with the consequence that the institutions' need for the resources is exaggerated. Preoccupation with expanding the availability of resources could also stifle the innovation of creative ways of making the best use of the resources available. This means that the institutions need to evaluate their utilization of these resources-to pinpoint their need for the resources and potential for quality assurance. This paper reports the findings of a study that responded to this need, taking the case of teaching space at Makerere University. The objective of the study was to verify the hypothesis that the University is teaching space constrained. The findings were that the resource is overly underutilized albeit this was disguised by occasional overutilization of the same space, a concomitance that only multidimensional evaluation could unearth. Accordingly, the study gives credence to the hypothesis that shortages of resources at the University, and similar institutions, are ostensible. Therefore, it is recommended that these institutions subject their utilization of resources to rigorous evaluation.
\end{abstract}

Keywords $\cdot$ Resources management $\cdot$ Higher education funding $\cdot$ Educational administration

\section{Introduction}

Many HEIs in Sub-Saharan Africa are operating with encumbering resources constraints that threaten quality assurance (Materu, 2007; Teferra and Altbach, 2004). Accordingly,

\footnotetext{
${ }^{1}$ Uganda Martyrs University. *Corresponding author: jssempebwa@umu.ac.ug.

2 Kampala International University, Dar es Salaam Campus.

3 East African School of Higher Education Studies and Development, Makerere University.
} 
they are working to expand the availability of these resources. Notwithstanding, it is taken for granted that once available, these resources are optimally utilised and that, in instances expanding their availability is not possible, compromising on some elements of the quality of higher education is inevitable. The problem is that this presumption could disguise inadequacies in the utilisation of the resources that the institutions have, with the consequence that the institutions' need for the resources is exaggerated. Therefore, there is need to evaluate the institutions' utilisation of these resources-to pinpoint their need for the resources and potential for quality assurance. This paper reports the findings of a study that responded to this need, taking the case of teaching space at Makerere University-a flagship institution in Sub-Saharan Africa that typifies the resources' constraints that have been reported to be encumbering many institutions in the region (Kasozi, 2003).

\section{Makerere University}

Makerere University, Uganda's flagship higher education institution (Lejeune, 1999), was established in 1922 as a technical college, by the British colonial administration in East Africa. The main aims of establishing the institution were to: 1) provide completers of secondary education with higher education - so that they do not seek it outside Africa (where they could copy political independence activism); and 2) produce manpower for positions in the colonial administration (Ssekamwa, 1997; Tiberondwa, 1998). Though it developed into an institution of notable repute in the Sub-Saharan African region (Altbach, 2005; Nakanyike and Nansozi, 2003; Sicherman, 2005; Eisemon and Salmi, 1993), therefore, it tended to be elitist-enrolling only a few students (all of whom were sponsored by the government of Uganda) and offering courses of study only in a few areas (primarily targeted at meeting the human resource needs in the colonial government's service).

During the 1970s and 1980s, however, the University was grossly underfunded (by the government) - due to the country's economic downturn and subsequent adoption (in the mid-1980s) of IMF/ World Bank recommended structural adjustment programs that discouraged government spending on higher education (Mamdani, 2007). According to Mayanja (1996), this affected the University's potential for quality assurance. Physical resources dilapidated; staff salaries were outstripped by inflation, thereby leading to moonlighting and attrition; and curricula were not reviewed, at the expense of the relevance of the University's study programs to the country's human resource-related needs. At the same time, pressure mounted on the University to expand its student intake, since barely $22 \%$ of admissible applicants were being accepted (Planning and Development Department, Makerere University, PDD, 2000) yet the institution was the only university in the country.

Starting the early 1990s, therefore, the University started enrolling fee-paying students (Mayanja, 1996). This improved the University's funding situation-thereby enabling refurbishment of some physical structures; upward revision of staff benefits and, subsequently, attraction of academic staff. It also reduced the university education demand-supply gap in the country (from $22 \%$ in 1986, for example, the percentage of admissible applicants accepted rose to $46 \%$ in 2005); and accelerated curriculum innovation-as teaching departments devised study programs for the new students (Altbach, 2005; Byaruhanga, 2002). 
Since the mid-1990s, therefore, the expansion of student intake at the University has been credited for contributing to the reformation of the University (see, for example, Court, 1999; Kassam, 1999; Mayanja, 1996; PDD, 2000).

\section{Shortage of Teaching Space at Makerere University}

Despite the contribution of expanded student intake to Makerere University's transformation, the University's strategic plans for the period 2000 to 2008 and 2008 to 2018 (PDD, 2000; 2008) indicate that the University is constrained by lack of sufficient teaching space-to accommodate the increasing number of students. Indeed, casual observation of teaching sessions at the University shows that, often, students are congested in, and sometimes overflow from, the rooms where their lecture sessions take place, which affects the quality of teaching and learning.

To surmount this constraint, the University has mainly implemented three interventions: 1) reducing the proportion of eligible applicants admitted (Figure 1; Ahimbisibwe, 2007; 2008; Luboobi, 2007); 2) construction of additional lecture rooms ${ }^{2}$ (Table 1); and 3) mounting of classes, usually in roomy areas of non-teaching units (like dining halls in halls of residence at the University) (see Namutebi, 2012; Ssekamwa, 2000).

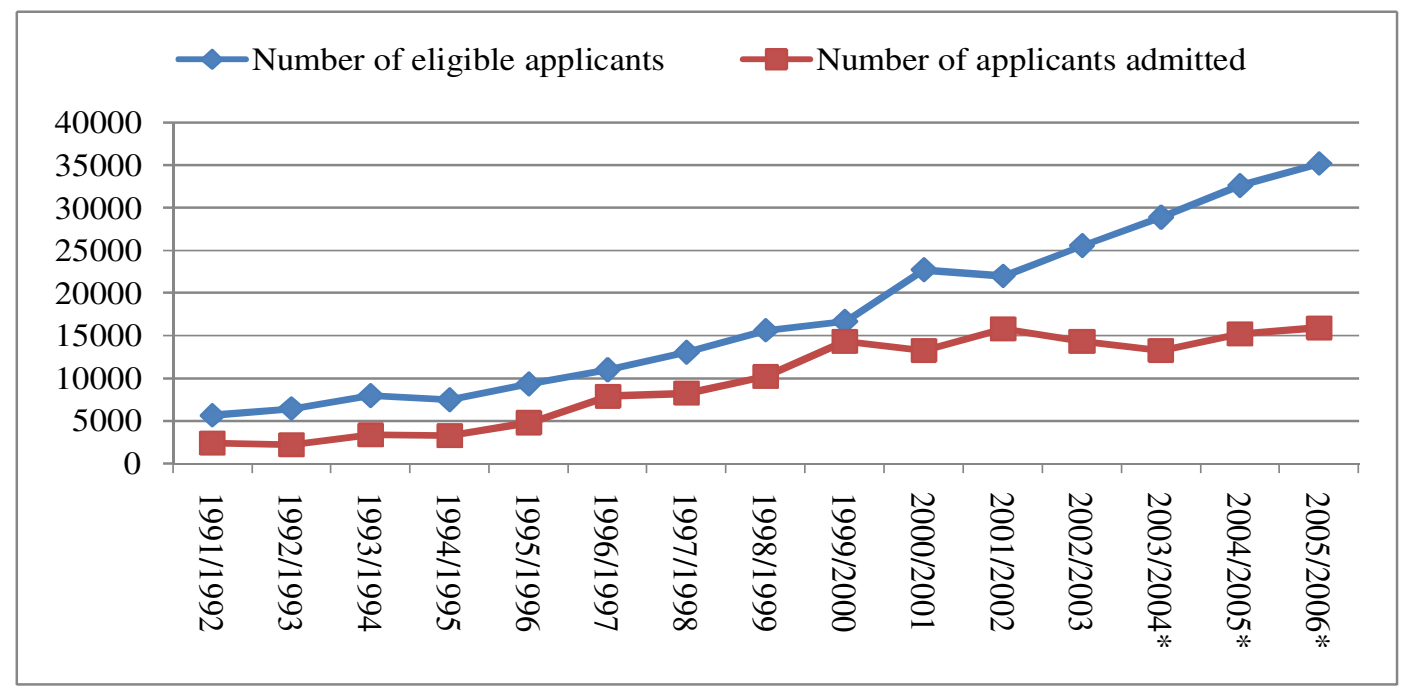

Figure 1: Eligible and admitted applicants at Makerere University (1991-2005)

*Figures exclude Makerere University Business School

Source: Byaruhanga (2007)

Table 1: Expansion of Academic Space at Makerere University (1994-2007) $\left(\mathrm{m}^{2}\right)$

\begin{tabular}{lllllll}
\hline & Classrooms & Laboratories & Workrooms & Communal & Circulation & Gross Area \\
\hline $1994 / 1995$ & 9832 & 22467 & 12933 & 7815 & 13834 & 66881 \\
$2006 / 2007$ & 19262 & 26719 & 16999 & 14175 & 22000 & 99146 \\
Difference & 9430 & 4252 & 4066 & 6360 & 8166 & 32265 \\
$\%$ Expansion & 96 & 19 & 31 & 82 & 59 & 48 \\
\hline
\end{tabular}

Source: Makerere University (2010)

${ }^{2}$ Lecture room is used to refer to all indoor areas that are used for instruction (including laboratories, studios, workshops, theatres and seminar rooms). 
However, reducing the proportion of eligible applicants admitted is at the expense of access to higher education. This presents as an important problem because over 120,000 students require admission to higher education (NCHE, 2004a) and Makerere, whose enrolment is barely 40,000, is expected to absorb a significant number of these applicants, being the country's flagship university (Lejeune, 1999). Even though new, and transnational, higher education institutions are expected to accommodate applicants the University cannot admit, these institutions are not likely to do so, since most of them have emerged as mere 'demand-absorbing' diploma mills established to cash in on higher education (Altbach, 2006; 2006a; 2006b; 2005a; Askehave, 2007; Materu, 2007). Second, reducing the number of (fee-paying) students affects the university's funding. Third, construction of lecture rooms costs enormous financial resources, whose opportunity cost cannot be overlooked. Finally, mounting of classes, and improvising of structures that were not customised for teaching (e.g. dining halls) as lecture rooms, is at the expense of quality assurance in instruction.

Nevertheless, implementation of the interventions is considered expedient, due to an implicit assumption that the capacity of the University's space to accommodate students has been exhausted. This study examined the validity of this assumption-through evaluating the optimality of the utilisation of the lecture rooms.

\section{Concept of Teaching Space}

Teaching space refers to areas that are set aside for use in instructing students. It could be indoor or outdoor. However, in this paper, reference is made only to indoor teaching space because it is the most commonly used space in higher education study programs. There are three dimensions to the availability of this space in an institution: the number of lecture rooms; the size of each of the rooms, in terms of the number of students that they can accommodate at a time; and the number of time periods for which each of the rooms is available for use in a teaching session. Though it is often taken for granted, teaching space merits attention in educational planning because, often, its availability is indispensable in instruction (Bray, 2008; Akinsolu, 2004) yet, unlike the procurement of other inputs into the teaching and learning process, its erection is very expensive.

\section{Theoretical Underpinning}

Conceptualisation of the study was hinged on Juran's generalisation of Vilfredo Pareto's Theory cited by Lipsey and Chrystal (1999). The theory was used because it has been suggested for the conceptualisation of studies of efficiency in the utilisation of resources (see, for example, Reh, 2005). According to the theory, optimality in the utilisation of resources is attained when it is impossible to reallocate consumption activities to make one person better off without making anyone worse off. On the contrary, the 80-20 principle of the theory contends that organisations derive $80 \%$ of their value from $20 \%$ of their resources (Evans and Wolf, 2005), meaning that they leave the $80 \%$ to waste. Arguing for departure from this underutilisation of resources, therefore, Juran opines that optimality in the utilisation of resources necessitates movement from the 80-20 level to a 100-100 level, where each resource input produces a proportionate or more than proportionate level of output.

In the context of evaluation of the optimality of utilisation of teaching space, therefore, optimum use of space corresponds to a situation in which it is impossible to admit a 
student into a lecture room without removing another or impinging on the suitability of the size of the class because:

There is a difference between maximising and optimising the use of [teaching] space.

To fix a class of 30 into a lecture room with 15 places would be increasing the use of space but the teaching/ learning situation may be undesirable. Maximisation of the utilisation of teaching space does not take into account conveniences in the technology of knowledge acquisition. The rate of use that provides the highest economic efficiency is the maximum while the one that provides ideal pedagogical conditions, and is the most economically efficient under that ideal condition, is the optimum (Owolabi, 1995a: 7).

This (optimum) rate is in reference to standards (of use of space) as prescribed by relevant authorities so evaluation of use of space should follow an approach that judges use against prescribed standards.

\section{Evaluation of Use of Teaching Space}

Owolabi (1995b) suggests three dimensions to the evaluation of the utilisation of teaching space. In the first, Frequency of Use of Teaching Space or Time Utilisation Rate (TUR), the ratio of the number of time periods for which a room is in use to the number of periods for which it should be used is established. In the second, Occupancy of Teaching Space or Space Utilisation Rate (SUR), the ratio of the number of students occupying a room to the number of students that should occupy the room is established. The third, Global Utilisation Rate (GUR), obtains the product of SUR*TUR, to establish the overall rate of use of space. TUR and SUR focus only on one of the dimensions to the availability of teaching space in an institution. Conversely, GUR exposes the overall rate of use of space; however, it does not illustrate the institution's use of the frequency of use and occupancy capacity of its teaching space. To pinpoint optimality in use of space, therefore, evaluation of the rate of use of space should follow a multidimensional approach-integrating all the three dimensions to the evaluation of the utilisation of teaching space (Owolabi, 1995b).

\section{Knowledge Gap and Objective}

At Makerere, however, related literature (e.g. Luboobi, 2007; PDD, 2008) shows that utilisation of teaching space has not been subjected to multidimensional evaluation. It is taken for granted that the space is inadequate because, during the 1990s, proponents of enrolment expansion at the University focused on maximising the occupancy of space, with the consequence that, often, students were congested in lecture rooms. However, upon multidimensional evaluation of the rate of use of teaching space, Owolabi (1995c; 1993) found that lecture rooms that were thought to be inadequate at three Ghanaian higher education institutions had unutilised capacity to accommodate students, the inference being that teaching space inadequacies deduced from congestion of students in learning areas might be more of apparent than real. Therefore, multidimensional evaluation of the utilisation of space at the University was conducted.

The optimum occupancy capacity of rooms was computed at the rate of $2.5 \mathrm{~m}^{2}$ per student for classroom space and $3 \mathrm{~m}^{2}$ per student for laboratories. These standards were taken to be appropriate because they are the ones that universities in Uganda are obligated to adhere to and their recommendation by the country's NCHE as ideal (cf. Table 2) is 
based on consideration of both aspirations for quality assurance in higher education and the country's higher education operating context.

Table 2: NCHE's Standards for Occupancy of Teaching Space in Ugandan Universities

\begin{tabular}{llllll}
\hline & & \multicolumn{4}{c}{ Standard } \\
& Ideal & Good & Acceptable & Can be improved & Unacceptable \\
\hline Classroom space & $2.5 \mathrm{~m}^{2}$ per 1 & $2 \mathrm{~m}^{2}$ per 1 & $1 \mathrm{~m}^{2}$ per 1 & $1 \mathrm{~m}^{2}$ per 4 student & $1 \mathrm{~m}^{2}$ per over \\
& student & student & student & & 5 student \\
Science & $3 \mathrm{~m}^{2}$ per 1 & $2.5 \mathrm{~m}^{2}$ per 1 & $1 \mathrm{~m}^{2}$ per 1 & $1 \mathrm{~m}^{2}$ per 4 student & $1 \mathrm{~m}^{2}$ per over \\
laboratories & student & student & student & & 5 student \\
Computer & $3 \mathrm{~m}^{2}$ per 1 & $2.5 \mathrm{~m}^{2}$ per 1 & $1 \mathrm{~m}^{2}$ per 1 & $1 \mathrm{~m}^{2}$ per 4 student & $1 \mathrm{~m}^{2}$ per over \\
laboratories & student & student & student & & 5 student \\
\hline
\end{tabular}

Source: NCHE (2004b)

Regarding frequency of use of space, eight hours a day, Monday to Friday, were taken as the optimum frequency of use of rooms because the conventional workweek is 40 hours distributed across these days.

Therefore, occupying a teaching area at the rate of $2.5 \mathrm{~m}^{2}$ per 1 student (classroom space) and $3 \mathrm{~m}^{2}$ per 1 student (laboratories) was taken to correspond to a SUR of 100 (percent), meaning that removing or adding one student would result into underutilisation or over-utilisation respectively. Similarly, using a teaching area for all the 40 hours was taken to correspond to a TUR of 100 (percent), meaning that reducing or increasing the number of hours for which the room is in use by one hour would result into under- and over-utilisation respectively. It has been argued that, in real life, HEIs may not be expected to attain this (100 percent) rate of use of space-due to disciplinary peculiarities and facilitation inadequacies that may constrain the use of space. However, understanding the significance of the difference between the rates of use achieved in practice and this theoretical optimum may guide improvement. It may also disaggregate the contribution of teaching space inadequacies from that of other factors to limiting access to quality higher education. Therefore, the study delved into the difference between the rate of use of space at the University and this optimum rate (100). Informed by Owolabi (1995c; 1993), it was hypothesised that there is a significant difference between the two.

\section{Methodology}

\section{Design}

The study was carried out following a case study design. Notwithstanding, it is offered for possible generalisation to Sub-Saharan Africa, given Makerere University's similarity with other HEIs in the region. Using documentary analysis, data were collected on the utilisation of lecture rooms during Semester Two of Academic Year 2009-2010. This data were complemented with data on the factors influencing the utilisation of the lecture rooms studied (collected through observation of the rooms and interview of the officers in charge of their utilisation).

\section{Population and Sample}

Three of the 22 teaching units in the University, namely, [the] Faculty of Science; Faculty of Arts; and School of Education, were purposely involved in the study. These have 40 
lecture rooms, all of which were studied. The justification for the selection of a few of the teaching units is that detailed data was necessitated on the rate of use of each of the rooms and its effective collection, management, analysis and presentation necessitated that only a few units are studied. Nevertheless, the three units were purposely selected to respectively represent the three categories of teaching units in the University (i.e. science and technology; arts and humanities; and mixed). Compared to the other teaching units in the University, the three teaching units have the biggest number of lecture rooms, teaching departments and students, so they were taken to be satisfactorily representative of the other teaching units.

\section{Data Sources and Collection Instruments}

Table 3 shows the data sources, collection techniques and instruments that were used.

Table 3: Data Categories, Sources and Collection Instruments

\begin{tabular}{|c|c|c|c|}
\hline Data & Source & Technique & Instrument \\
\hline Occupancy capacity of lecture rooms & Lecture rooms & Measurement & Dimension calculator \\
\hline Frequency of use of lecture rooms & $\begin{array}{l}\text { Teaching } \\
\text { timetables }\end{array}$ & $\begin{array}{l}\text { Documentary } \\
\text { analysis }\end{array}$ & Survey checklist \\
\hline Occupancy of lecture rooms & Student lists & $\begin{array}{l}\text { Documentary } \\
\text { analysis }\end{array}$ & Survey checklist \\
\hline $\begin{array}{l}\text { Factors influencing rate of use of } \\
\text { lecture rooms }\end{array}$ & $\begin{array}{l}\text { Informants/ lecture } \\
\text { rooms }\end{array}$ & $\begin{array}{l}\text { Interview/ } \\
\text { observation }\end{array}$ & $\begin{array}{l}\text { Interview guides/ } \\
\text { checklist }\end{array}$ \\
\hline
\end{tabular}

A checklist cross tabulated time (in rows) and days of the week (in columns), so figures on the number of students assigned to a lecture room during a given hour on a given day were entered in the cells of the checklist. The Faculty Administrators in the Faculties of Arts and Science and Timetable Master in the School of Education were interviewed on the reasons as to why the rooms were used the way they were used and their responses validated through observation of the utilisation of the rooms.

\section{Data Quality Assurance}

Consistency in the measurement of the rooms was ensured through using a dimension calculator that electronically images and records dimensions, thereby minimising chance of error. The survey checklist was pre-tested, to ensure that it was appropriately structured to collect the data necessitated. Thereafter, it was revised as had been found needful and a Microsoft Excel template, into which relevant formulae and error notification facilities were programmed, was developed to handle the data.

\section{Analysis}

The area $\left(\mathrm{m}^{2}\right)$ of each of the teaching areas was calculated as $\mathrm{L} * \mathrm{~W}$ (where $\mathrm{L}=$ Length and $\mathrm{W}=$ Width) and divided by 2.5 (classrooms) or 3 (for laboratories), to determine the ideal number of students that the areas can accommodate (Table 2). The weekly frequency of use capacity of the rooms was taken to be 40 hours. On the other hand, the weekly occupancy capacity of the rooms was established as the number of students a room can accommodate in a teaching period multiplied by the number of teaching periods in the teaching week (40). To establish the rate at which the rooms were used, their TUR, SUR 
and GUR were calculated. For each of the three teaching units, the TUR, SUR and GUR (of the rooms in the unit) formed a distribution. To test the hypothesis that there is a significant difference between the rate of use of space and the optimum rate (100), these distributions were subjected to one sample t-tests, at the level of $\alpha=.05$, using 100 as the test value. The interviewees' responses and observation notes taken were studied and the reasons underlying the rate of use of teaching space established that they pointed out identified.

\section{Findings}

The findings on the rate of use of lecture rooms are summarised in Table 4.

Table 4: Rate of Use of Teaching Areas

\begin{tabular}{|c|c|c|c|c|}
\hline Teaching Unit & Teaching Area & TUR & SUR & GUR \\
\hline \multirow{18}{*}{ School of Education } & Biology Laboratory & 19 & 22 & 4 \\
\hline & Conference Hall & 67 & 71 & 47 \\
\hline & Chemistry Laboratory & 14 & 8 & 1 \\
\hline & Computer Laboratory & 17 & 4 & 1 \\
\hline & DOSATE & 8.6 & 14 & 1 \\
\hline & Ground 13 & 13 & 4 & 1 \\
\hline & Lecture Theatre & 44 & 66 & 29 \\
\hline & Off. Fre & 23 & 25 & 6 \\
\hline & Off. Germ & 23 & 3 & 1 \\
\hline & PhD Room & 29 & 4 & 1 \\
\hline & Physics Laboratory & 24 & 9 & 2 \\
\hline & Room 1 & 41 & 43 & 18 \\
\hline & Room 2 & 48 & 53 & 25 \\
\hline & Room 3 & 42 & 50 & 21 \\
\hline & Room 4 & 36 & 36 & 13 \\
\hline & Room 126 & 10 & 1 & 0 \\
\hline & Room 127 & 30 & 15 & 4 \\
\hline & Total & 29 & 25 & 7 \\
\hline \multirow{11}{*}{ Faculty of Science } & $\mathrm{BOT} / \mathrm{ZOO}$ & 42 & 20 & 8 \\
\hline & Chemistry Main & 37 & 7 & 3 \\
\hline & Chemistry Small & 28 & 24 & 7 \\
\hline & JICA 201/202 & 31 & 5 & 2 \\
\hline & JICA 204 & 39 & 23 & 9 \\
\hline & JICA 205 & 42 & 19 & 8 \\
\hline & MS 105 & 22 & 16 & 4 \\
\hline & MS 203 & 31 & 25 & 8 \\
\hline & Physics Main & 39 & 12 & 5 \\
\hline & Physics Small & 29 & 41 & 12 \\
\hline & Total & 34 & 19 & 6 \\
\hline \multirow{14}{*}{ Faculty of Arts } & Geography Laboratory 1 & 46 & 40 & 18 \\
\hline & Geography Laboratory 2 & 49 & 53 & 26 \\
\hline & Lower Building 1 & 61 & 53 & 32 \\
\hline & Lower Theatre & 70 & 83 & 58 \\
\hline & Lecture Room 1 & 43 & 46 & 20 \\
\hline & Lecture Room 2 & 56 & 71 & 40 \\
\hline & Lecture Room 3 & 21 & 53 & 11 \\
\hline & Lecture Room 4 & 23 & 34 & 8 \\
\hline & Lecture Room 5 & 42 & 44 & 18 \\
\hline & Lecture Room 6 & 56 & 65 & 37 \\
\hline & Upper Building 1 & 72 & 53 & 39 \\
\hline & Upper Building 4 & 9.5 & 12 & 1 \\
\hline & Upper Theatre & 70 & 88 & 62 \\
\hline & Total & 48 & 53 & 28 \\
\hline
\end{tabular}


Table 5 shows the significance of the difference between the current and optimum rate of use of teaching space.

Table 5: One-Sample Test for Significance of Difference between Current and Optimum Rate of Use of Space

\begin{tabular}{|c|c|c|c|c|c|c|c|c|c|}
\hline \multirow{2}{*}{$\frac{\text { Test value }=100}{\text { Dimension }}$} & \multicolumn{3}{|c|}{$\begin{array}{c}\text { School of Education } \\
\mathrm{n}=17, \mathrm{df}=16, \text { critical value of } \mathrm{t}=1.74\end{array}$} & \multicolumn{3}{|c|}{$\begin{array}{c}\text { Faculty of Science } \\
\mathrm{n}=10, \mathrm{df}=9, \text { critical value } \\
\text { of } \mathrm{t}=1.83\end{array}$} & \multicolumn{3}{|c|}{$\begin{array}{c}\text { Faculty of Arts } \\
\mathrm{n}=13, \mathrm{df}=12, \text { critical } \\
\text { value of } \mathrm{t}=1.78\end{array}$} \\
\hline & TUR & SUR & GUR & TUR & SUR & GUR & TUR & SUR & GUR \\
\hline Std. Dev & 15.64 & 23.46 & 13.46 & 6.72 & 10.31 & 3.22 & 19.06 & 20.29 & 18.23 \\
\hline Std. error & 3.7 & 5.6 & 3.2 & 2.1 & 3.2 & 1 & 5.2 & 5.6 & 5 \\
\hline Mean & 29 & 25 & 10 & 34 & 19 & 6 & 48 & 53 & 29 \\
\hline Mean difference & -71 & -75 & -90 & -66 & -81 & -94 & -52 & -47 & -71 \\
\hline Calculated value of $t$ & -18.79 & -13.13 & -27.46 & -31.09 & -24.78 & -91.82 & -9.77 & -8.27 & -14.11 \\
\hline
\end{tabular}

\section{Frequency of Use of Teaching Space (TUR)}

Table 4 shows that the overall (total) TUR was established at 29\%, 34\% and $48 \%$ for the School of Education, Faculty of Science and Faculty of Arts respectively. This implies that, for most of the hours during the teaching week, the lecture rooms are unused. The analysis in Table 5 indicates that, for each of the teaching units, the difference between the mean TUR established and the optimum rate of use (100) is statistically significantcalculated values of $\mathrm{t}>$ critical values of $\mathrm{t}$-meaning that the time periods for which the lecture rooms should be used are not optimally utilised.

\section{Occupancy of Teaching Space (SUR)}

Table 4 indicates that the overall SUR in the School of Education, Faculty of Science and Faculty of Arts was established at 25\%,19\% and 53\% respectively. In fact, it shows that, for some of the rooms, less than $10 \%$ of weekly occupancy capacity was utilised. Incidentally, in the School of Education and Faculty of Science, the overall (total) SUR was less than the respective TUR, meaning that for some of the time periods the rooms were in use, they were not fully occupied. Ironically, in the School of Education and Faculty of Arts, analysis of the occupancy of lecture rooms per hour showed that students were congested in many of the lecture rooms during many of the few hours for which the rooms were used. This means that there is concomitance of over- and under-utilisation of the rooms (something that only a multidimensional analysis could expose).

\section{Understanding the Suboptimal Utilisation of Teaching Space}

To understand the reasons as to why the lecture rooms were not optimally utilized, the officers in charge of timetabling their utilization were asked why they; 1) timetabled the rooms [in particular those that had the lowest TUR] to be used for fewer hours [and days] than there are on the University's timetable; 2) assigned fewer students than can fit into the rooms [in particular those that had the lowest SUR]; and 3) assign more students to some of the rooms [in particular those in which students were congested] than can fit there with adherence to the standard of suitability of class size.

The size (in terms of student intake capacity) of rooms was found to influence the extent to which they were utilized, with large rooms being put to more intensive utilization. Observation indicated that these were mostly constructed in conference or 
theatre design; had raked floors and customized furniture (mostly setup in classroom style); were fitted with stages; had loud speaker facilities; were fitted with projection screens; were relatively tall; and were lit by white fluorescent bulbs. In the Faculty of Science, however, the smaller rooms were used more intensively. The interviews revealed that the association between the nature of teaching spaces and their rate of use is related to the modal class sizes in the teaching units. The respondents explained that;

"...the smaller lecture rooms cannot accommodate many of the groups [of students]so most lectures are assigned to the big rooms [Conference Hall, Lecture Theatre and Lecture Rooms 1, 2, 3 and 4]. The smaller groups [of students] are then assigned to the smaller [lecture] rooms; but then some of the groups are still too small to fill up the small [lecture] rooms. Regarding overutilization [congestion of students in lecture rooms], some of the [large] classes are still too big to fit in the big rooms." (Interview with Timetable Master at the School of Education).

It was also explained that;

"At the central level, all the lecture rooms are assigned for use for all the hours in the teaching week. However, [the teaching] departments reschedule their classes from the smaller rooms to larger ones, where large classes can be accommodated." (Interview with Faculty Administrator at the Faculty of Arts).

Incidentally, observation of the 'small' rooms indicated that, unlike the 'large' rooms, many of them are not fully dedicated to the instruction of students. In the School of Education, for example, part of Room 126 is used to store obsolete materials while part of OFF. GERM. and OFF. FRE. is used as office space, characteristics that cutback on the student intake capacity of the rooms. It was also observed that some of the 'small' rooms were lit by yellow bulbs, which could limit their utilization to daylight lit hours (hence a low TUR). This suggests that, on account of their nature, the 'small' lecture rooms are put to less frequent use and are not fully occupied during the few hours for which they are utilized. On the contrary, on account of their characteristics, the 'large' rooms are assigned to accommodate classes that are too big for quality pedagogy to be expected while at other times their capacity to accommodate students is underutilized, at the expense of students being admitted. In the Faculty of Science, on the other hand, the 'higher' rate of use of the 'smaller' rooms was attributed to the fact that;

"...students are assigned to the different rooms in accordance with their needs and purpose of the rooms; variations in the rate of utilization [of student intake capacity] arise out of the fact that the smaller groups of students fill up the smaller rooms better than they do larger rooms." (Interview with Faculty Administrator at the Faculty of Science).

These findings point to the nature of lecture rooms, and classes, at Makerere as candidates for modification-if access to the University; quality in pedagogy; or both are to be enhanced. Rather than leave them unused, the 'small' rooms (in the School of Education and Faculty of Arts) could be expanded to make them amenable to large classes. This might allow enrolment of more students. In the Faculty of Science, on the other hand, more students could be admitted, to make use of the student intake capacity of rooms that is underutilized. This, too, could expand access to the University. Nonetheless, both these interventions might affect the suitability of class sizes for quality pedagogy. After all, it 
was found that, notwithstanding their enormity, at some stage, even the large rooms cannot accommodate large classes under satisfactory conditions of quality assurance. Alternatively, classes that cannot fit into the 'small' rooms could be split (to fit) and large lecture rooms split into sections that are customized to accommodate small classes without redundant occupancy capacity. This would optimize the rate of use of both the small and large rooms and, subsequently, reduce the gap between the number of student places used and those that the rooms can offer (c.f. Table 4). This would require more lecturer hours, to cover the increased number of classes, and flexible lecture room partitioning technology, to tailor sections of (large) rooms to small classes.

Inadequacy of students, lecturers and teaching aids was also found to underlie the suboptimal utilization of teaching space. In teaching units/ departments that had a shortage of students, lecture rooms were underutilized, because fewer lectures than are possible to attain on the University's teaching timetable were required and, even then, the lecture rooms were not fully occupied during these lectures. In the Faculty of Science, this was explicated by the Faculty Administrator thus;

"... all the courses that have to be taught in a semester are put [scheduled] on the timetable...there is no way we can put more lectures".

In teaching units/ departments that have a shortage of lecturers, too many students were assigned to the rooms (in lieu of splitting oversized classes and scheduling more lectures). In the School of Education, the Timetable Master explained that;

"....it is not easy to keep on splitting large classes. Already, some courses, especially foundational courses, are taught in groups [of students]; but each time a new group is created, more lecturers are needed to attend to it... [but] there aren't as many lecturers...".

The respondents also indicated that large classes allow savings of teaching aids, because few lectures are conducted.

\section{Discussion and Conclusions}

\section{Implications for Intake Capacity Planning at Makerere University}

Suboptimal utilisation of teaching space at Makerere implies that the University is not teaching space constrained, contrary to Luboobi (2007) and PDD (2000; 2008). Second, the simultaneity of over- and under-utilisation of space affirms that inadequacies in the availability of space that are deduced from congestion of students in teaching areas may be more apparent than real. Thus, this study brings the rationale underlying the University's construction of new lecture rooms and contraction of student intake to question. Rather, it suggests that the University should: 1) partition its large teaching areas into smaller lecture rooms; 2) split its large classes into groups that fit into the smaller lecture rooms; and 3) replicates lecture sessions until the hours for which the lecture rooms are available are put to optimum use. This will not only optimise the rate of use of teaching space but also result into creation of extra student places albeit in smaller classes, which may permit better quality teaching and learning.

Undoubtedly, university classes and teaching areas are usually unique in ways that may make them difficult to split. It may also be argued that, owing to its peculiarity, university 
teaching may not be expected to reach optimum (100 percent) rates of use of space. Replicating lecture sessions would also require employment of more lecturers and provision of more teaching aids.

Nevertheless, devising innovative and flexible teaching area partitioning technology that takes cognizance of relevant university-teaching-related idiosyncrasies could significantly reduce the gap between the current and optimal rates of use of space. Standing at 7\%, 6\% and 28\% for the School of Education, Faculty of Science and Faculty of Arts respectively (Table 4), the (global) rate of use of space in the teaching units (and, therefore, Makerere University) shows plenty of room for improvement.

Regarding availability of lecturers and teaching aids, conceptualisation of the study was based on the understanding that, once the availability of teaching space is increased, the University can provide the lecturers and teaching aids required to use the extra space. This is because shortage of space, rather than shortage of lecturers and teaching aids, had been reported to be constraining the University's ability to expand its student intake. Moreover, unlike the overhead nature of the cost of constructing new teaching areas, the cost of employing more lecturers and procuring more teaching aids may be met through the fees the students pay.

\section{Beyond Teaching Space and Makerere University}

The finding that teaching space at Makerere is overly underutilised but that this underutilisation is concealed by over-utilisation of the same space during some periods of the teaching week suggests that inadequacies of resources at the institution may not be as dire as they seem. Second, it suggests that suboptimal utilisation, rather than inadequate availability, of resources is encumbering the University's efforts to assure quality. This means that focus on expanding resources should be complemented by focus on the optimality of their utilisation, a view that is corroborated by several authors (e.g. Adedeji et al., 2008; Oloyede, 2003). This points to need for evaluating the utilisation of resources. Nonetheless, the finding that under- and over-utilisation of space were concomitant suggests that the evaluation must follow a rigorous, in principle technical, approach that is grounded on an appropriate theoretical/ conceptual framework. In this study, for example, only a multidimensional approach grounded on Pareto Optimality Theory pinpointed this concomitance while casual observation of observation of lecture sessions suggested that teaching space at the University was grossly inadequate.

Beyond Makerere University, the researcher hypothesises that similar findings may be made about the utilisation of resources in other HEIs in Sub-Saharan Africa. In Ghana, for example, Owolabi $(1993 ; 1995 a ; 1995 c)$, concluded that quality assurance in HEIs related to factors pertaining to the deployment, rather than availability, of resources. Adedeji et al. (2008), Ssempebwa et al. (2007) and Galabawa (1991) reached similar conclusions in studies on Nigerian, Rwandan and Tanzanian HEIs respectively.

The inference here is that the institutions should not take it for granted that their resources are inadequate or optimally utilised. Rather, they should rigorously evaluate their utilisation of the resources. Government and donor agencies contacted by HEIs with requests to fund expansion of resources should also demand that the institutions demonstrate that their need for extra resources is based on rigorous evaluation of the utilisation of the resources they have. 


\section{References}

Adedeji, S. O., Okemakinde, T. \& Ssempebwa, J. (2008) "Teaching resources utilisation and academic performance in technical colleges in Oyo State, Nigeria", Nkumba Business Journal, 11, pp. 100-104.

Ahimbisibwe, F. (2007) Makerere cuts intake by 20\%. Online: http://www.newvision.co.ug/D/8/12/550635/Ahimbisibwe\%20F.\%202005,\%20Makere re\%20to\%20reduce\%20intake [accessed August 2010].

Ahimbisibwe, F. (2007) Makerere cuts intake by 20\%. Online: http://www.newvision.co.ug/D/8/12/550635/Ahimbisibwe\%20F.\%202005,\%20Makere re\%20to\%20reduce\%20intake [accessed August 2010].

Akinsolu, A. O. (2004) "Provision and management of facilities in Nigerian primary schools". In E. O. Fagbamiye, J. B. Babalola, M. Fabunmi \& A. O. Ayeni (eds.) Management of primary and secondary education Nigeria, pp. 98-121. Lagos: Nigerian Institute of Education Planning and Administration.

Altbach, P. G. (2005) "Contradictions of academic development: exploiting the professoriate and weakening the university". International Higher Education. Number 39, Spring (2005).

Altbach, P. G. (2005a) "Universities: family style". International Higher Education, Number 39, Spring (2005).

Altbach, P. G. (2006) "The anatomy of private higher education". In P. G. Altbach (ed.) International higher education: reflections on policy and practice, pp. 109-111. Boston: Boston College Centre for International Higher Education.

Altbach, P. G. (2006a) "The perils of internationalising higher education: an Asian perspective". In P. G. Altbach (ed.) International higher education: reflections on policy and practice, pp. 47-50. Boston: Boston College Centre for International Higher Education.

Altbach, P. G. (2006b) "The rise of the pseudo university". In P. G. Altbach (ed.) International higher education: reflections on policy and practice, pp. 103-107. Boston: Boston College Centre for International Higher Education.

Askehave, I. (2007) "The impact of marketisation on higher education genres-the international student prospectus as a case in point". Discourse Studies, 9(6), pp. 723742.

Bray, M. (2008) Double-shift schooling: design and operation for cost effectiveness. Third edition. London: Commonwealth Secretariat.

Byaruhanga, M. (2002) The paradox of curriculum innovation and implementation in a liberalised higher education system in Uganda: a challenge to Makerere University. Paper presented at the tenth general assembly of the Council for the Development of Social Research in Africa, Kampala, December, 2002.

Court, D. (1999) Financing higher education in Africa: Makerere, the quite revolution. Washington D. C.: Rockefeller Foundation and the World Bank.

Eisemon, T. O. \& Salmi, J. (1993) "African universities and the state: prospects for reform in Senegal and Uganda". Higher Education, 25(2), pp. 151-168.

Evans, P. \& Wolf, B. (2005) "Collaboration rules". Harvard Business Review, 83(7), pp. 96-104.

Galabawa, J. C. J. (1991) "Funding, selected issues and trends in Tanzania higher education". Higher Education, 21(1), pp. 49-61. 
Kasozi, A. B. K. (2003) University education in Uganda: challenges and opportunities for reform. Kampala: Fountain Publishers.

Kassam, A. (1999) "University education in Uganda: quality despite adversity". The UNESCO Courier, No. 173, January-February.

Lejeune, M. (1999) "Higher education in Uganda". International Higher Education, Number 14, Winter (1999).

Lipsey, R. G. \& Chrystal, A. K. (1999) Principles of Economics. Ninth edition. Oxford: Oxford University Press.

Luboobi, S. L. (2007) Address by the vice chancellor on the occasion of the $54^{\text {th }}$ and $55^{\text {th }}$ graduation ceremonies on Thursday $22^{\text {nd }}$ and Friday $23^{\text {rd }}$ February 2007. Online: http:/www.mak.ac.ug [accessed August 2010].

Makerere University (2010) Makerere University Fact Book 2009/10. Kampala: Makerere University Planning and Development Department.

Mamdani, M. (2007) Scholars in the marketplace: the dilemmas of neo-liberal reform at Makerere University, 1989-2005. Kampala: Fountain Publishers.

Materu, P. (2007) Higher education quality assurance in Sub-Saharan Africa: status, challenges, opportunities and promising practices. Washington D. C.: World Bank Working Paper Number 124.

Mayanja, M. K. (1996) The social background of Makerere University students and the potential for cost sharing. Accra: Association of African Universities.

Nakanyike, B. M. \& Nansozi, K. M. (2003) Makerere University in transition (19932000): opportunities and challenges. Oxford: James Currey.

Namutebi, J. (2012): Dining halls turned into teaching space at Makerere. Online: http://www.newvision.co.ug/news/632781-dining-halls-turned-into-teaching-space-atmakerere.html [accessed July 2012].

NCHE (2004a) The strategic plan for higher education 2003-2015. Kampala: NCHE.

NCHE (2004b) Checklist of quality and institution capacity indicators for assessment of institutions and programs under the Universities and Other Tertiary Institutions Act, 2001, Rules and Regulations No. 7. Kampala: NCHE.

Oloyede, D. O. (2003) "Resources availability, utilisation and academic achievement of students in selected secondary schools in Ibadan". Ibadan Journal of Educational Studies, 3(2), pp. 40-47.

Owolabi, S. O. (1993) Utilisation of teaching spaces and teaching time at the University College of Education Winneba. Accra: Ministry of Education and Culture Report Number 1.

Owolabi, S. O. (1995a) Utilisation of teaching spaces and teaching time at Kumasi Polytechnic. Accra: Ministry of Education and Culture Report Number 36.

Owolabi, S. O. (1995b) Mapping of school facilities. Ibadan: Department of distance education, University of Ibadan.

Owolabi, S. O. (1995c) "A case study on space management in the University of Ghana". In B. C. Sanyal (ed.) Institutional management in higher education in Western Africa, pp. 139-160. Paris: International Institute of Educational Planning.

PDD (2000) Makerere University strategic plan 2000/01-2004/05. Kampala: Makerere University.

PDD (2008) Makerere University Strategic Plan 2008/2009-2018/2019. Kampala: Makerere University. 
Reh, F. J. (2005) Pareto's principle-the 80-20 rule: How the 80-20 rule can help you to become more effective. Retrieved August 15, 2008 from: www.about.com.

Sicherman, C. (2005) Becoming an African university: Makerere, 1922-2000. Trenton: Africa World Press.

Ssekamwa, J. C. (1997) History and development of education in Uganda. Kampala: Fountain Publishers.

Ssekamwa, J. C. (2000) Measures to cope with large student numbers at Makerere University. Paper presented at the Makerere University Strategy Planning Workshop, Kampala, January 2000.

Ssempebwa, J., Canene, A. P. \& Mugabe, M. (2007) "ICT investment in Rwandan higher education: highlighting the cost of downtime and end-users' operations". Kampala International University Research Digest, 1(1), pp. 19-30.

Teferra, D. \& Altbach, P. G. (2004) "African higher education: challenges for the 21 st century". Higher Education, 47(1), pp. 21-50.

Tiberondwa, A. K. (1998) Missionary teachers as agents of colonialism: a study of their activities in Uganda, 1877-1925. Kampala: Fountain Publishers.

\section{Author Biography}

Dr. Jude Ssempebwa holds a $\mathrm{PhD}$ in higher education planning and management from the East African Institute of Higher Education Studies and Development, Makerere University College of Education and External Studies. He is a member of the African Higher Education Research Online (AHERO) project team; a member of American Education Research Association (AERA); a member of the Association of Research Administrators in Africa (ARAA); and a member of the Higher Education Research and Policy Network (HERPNET). His current research efforts focus on international higher education in Africa; management of educational resources in Sub-Saharan Africa; and quantitative methods of educational planning.

Dr. Samuel Olajide Owolabi (RIP) was a tenured Professor of education studies at Kampala International University, Dar es Salaam Campus. Formerly he was a Professor in the Department of Educational Management, University of Ibadan; a two-time commonwealth chair, at the University College of Education Winneba/ Ministry of Education and Culture, Ghana and the East African Institute of Higher Education Studies and Development, Makerere University; Director, School of Postgraduate Studies and Research, Kampala International University; and Deputy Vice-Chancellor, Kampala International University.

Dr. Fred Edward K. Bakkabulindi holds a PhD from Makerere University and a Master of Science degree in Social Statistics from Southampton University. Currently, he is a Senior Lecturer at the East African School of Higher Education Studies and Development, Makerere University College of Education. His research interests focus on doctoral pedagogies, educational measurement and innovation adoption in institutions of higher learning. 